\title{
Effect of Sisal Fibre on Partially Replaced Cement with Periwinkles Shell Ash (PSA) Concrete
}

\author{
*AFOLAYAN, JO; WILSON, UN; ZAPHANIAH, B \\ Department of Civil Engineering, Nigerian Defence Academy, Kaduna, Nigeria. \\ *Corresponding Author Email: ajoyeniyi@nda.edu.ng
}

\begin{abstract}
An investigation on the effect of sisal fiber on partially replaced cement with Periwinkle Shell Ash in Concrete was carried out. Sisal fiber of $40 \mathrm{~mm}$ length which forms $1 \%$ of the mix by weight with Periwinkle shell Ash as a partial replacement for cement was used to cast the concrete. Compressive strength test was carried out using $0 \%, 5 \%$, $10 \%, 15 \%, 20 \%, 25 \%$ and $30 \%$ of Periwinkle Shell Ash as partial replacements of cement at different curing ages of 7 , 14, 21 and 28 days. A skewed result was observed showing a significant increase in the compressive strength recorded in 21 and 28 days of curing whose peaks are at 5\% replacement of PSA in the fiber-reinforced-concrete after which, there was a continuous decline in compressive strength of concrete as the percentage of PSA increased. The peak compressive strength value of $28.8 \mathrm{~N} / \mathrm{mm}^{2}$ was obtained at $40 \mathrm{~mm}$ sisal fiber and at 28 days curing age. This is followed by a compressive strength value of $26.15 \mathrm{~N} / \mathrm{mm}^{2}$ after 21 days of curing, all gotten at $5 \%$ PSA replacement. This makes $5 \%$ the optimal and apparently an exclusive PSA content for Sisal fiber-reinforced-concrete.
\end{abstract}

\section{DOI: https://dx.doi.org/10.4314/jasem.v23i4.22}

Copyright: Copyright (C) 2019 Afolayan et al. This is an open access article distributed under the Creative Commons Attribution License (CCL), which permits unrestricted use, distribution, and reproduction in any medium, provided the original work is properly cited.

Dates: Received: 12 February 2019; Revised: 19 March 2019; Accepted 02 April 2019

Keywords: Sisal fibre, Periwinkle shell ash (PSA), Compressive strength, Concrete.

Periwinkle shell is a waste product generated from the consumption of a small greenish-blue marine snail (periwinkle), housed in a V-shaped spiral shell found in many coastal communities within Nigeria and worldwide. It is a very hard and brittle material. Snails called periwinkle are found in the lagoon sand mud flats of the Niger Delta between Calabar in the SouthSouth and Badagry in the West of Nigeria. The people in this area consume the edible part as sea food and dispose the shell as a waste, though few people utilize the shell as coarse aggregate in concrete in areas where there are neither stones nor granite for purposes, such as paving of water logged areas. A large amount of the shells are still disposed as waste though it still constitutes problem in areas where they are yet to find its significant use with yet a large deposit having accumulated in many places over the years. Considerable efforts are being taken worldwide to improve on the strength and durability of concrete through the use of pozzolanic materials. The commonly used pozzolanas have been fly ash, silica fume, metakaolin, and blast furnace slag. In the continuous quest for more cost - effective and environmentally friendly materials, recently, there has been a growing interest in the use of agricultural wastes as pozzolanas. Some of the pozzolanas of agricultural origin include sawdust ash (Sumaila and Job 1999; Udoeyo and Dashibil 2002), rice husk ash (Zhang and Malhotra 1996), corn cob ash (Adesanya 2001; Adesanya and Raheem 2009b; Adesanya and Raheem 2009a), palm oil fuel ash (Tangchirapat et al. 2009) and periwinkle shell ash (Badmuset al., 2007; Dahunsi and Bamisaye 2002; Job et al., 2009; Koffi 2008).Periwinkle Shell Ash (PSA) is obtained by burning periwinkle shell which is the by-product of periwinkle which, in zoology is any small greenish marine snail from the class of gastropod, the largest of the seven classes in the phylummollusc (Okon 1987; Olorunoje and Olalusi 2003). They are herbivorous and found on rocks, stones or pilings between high and low tide marks; on mud-flats as well as on prop roots of mangrove trees and in fresh and salt water. Dance (1980) observed that ten (10) out of the eighty (80) species of periwinkle in the world are found in West Africa. The common periwinkle (littorina littorea) is one of the most abundant marine gastropods in the North Atlantic, but tympanotonus fuscatus is commonly found in the estuaries and mangrove swamp forest of the South-South region of Nigeria (Badmus et al., 2007). Massive periwinkle harvesting has been reported from some communities in this region of Nigeria (Powell et al. 1985; Job 2008; Jamabo and Chinda 2010; Mmom and Arokoya 2010).Olutoge et al., 2013 observed that the compressive strength decreases as the percentage of 
Periwinkle Shell Ash (PSA) increases and for each of percentage replacement the compressive strength increases as the curing age increases which is an indication that the crushing strength increases with curing age increase .Fiber-reinforced concrete (FRC) is a cement-based composite material reinforced with discrete, usually randomly distributed fiber material. Fiber material of various shapes and sizes produced from steel, synthetics, glass, and natural materials can be used. However, for most structural purposes, steel fibers are the most used of all fiber materials, whereas synthetic fibers (e.g. polypropylene and nylon) are mainly used to control the early cracking (plasticshrinkage cracks) in slabs. Fiber reinforcement mainly enhances the post-cracking properties of concrete and leads to a more ductile material behavior. The increased ductility is due to the ability of the fibers to transfer tensile stresses across a cracked section, potentially leading to a reduction in crack widths. The extent of the crack width reduction depends on the amount of fibers added as well as their physical properties (e.g. surface roughness and chemical stability) and mechanical properties (e.g. tensile strength). Therefore, the focus of this research is to investigate the effect of Sisal fibre on partially replaced cement with periwinkles shell ash concrete.

\section{MATERIALS AND METHODS}

The major materials obtained as specimen for this research work include cement, sand, coarse aggregate, periwinkles shell, sisal fiber and water.

Ordinary Portland Cement (OPC): Ordinary Portland Cement (OPC) grade 42.5 conforming to BS 12 and relevant Nigeria Standard was sourced from local market at Panteka, Kaduna.

Coarse and Fine aggregate: Locally available river sand and crushed chippings of $20 \mathrm{~mm}$ maximum aggregate size were used as fine aggregate and coarse

aggregate respectively. They were sourced from a local supplier at Tunduwada, Kaduna.

Periwinkle shell: Periwinkle shells used for this research work were sourced from Yenagoa, Bayelsa State. They were washed clean and allowed to dry before poured into an open perforated pan where it is subjected to fire to be burn locally using firewood. Thereafter it was taken for grinding at Pantaka Market, Tudun Wada, Kaduna after which it was sieved using $200 \mu \mathrm{m}$ sieve.

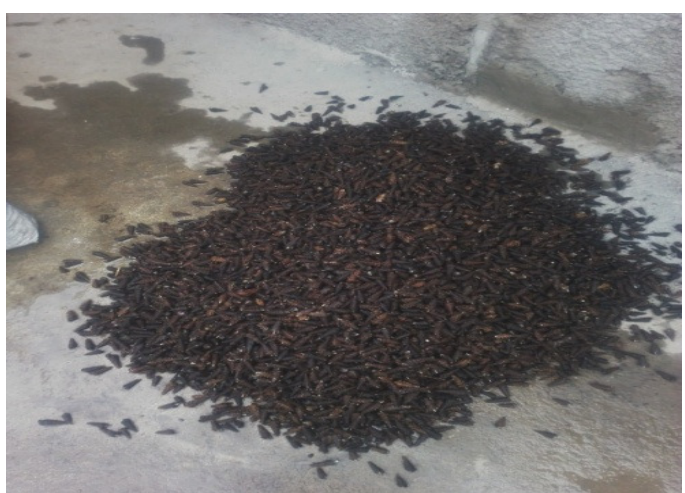

Plate 1. Showing Periwinkle Shell used for the Experiment

The Sisal fiber used for the experiment was sourced from Panteka market Tudun Wada, Kaduna it was cut into $40 \mathrm{~mm}$ length. The results of the properties of the Sisal fibre was adopted work carried out by Saniet al, 2017

Table 1. Properties of the sisal fibre (Sani et al, 2017)

\begin{tabular}{ll}
\hline Property & Quantity \\
\hline Natural humidity, \% & 14.48 \\
Average diameter, mm & 0.13 \\
Water absorption, \% & 340 \\
Specific gravity & 0.22 \\
Tensile strength of 1 strand, N/mm & 10.60 \\
Tensile strength of 2 strand, $\mathrm{N} / \mathrm{mm}^{2}$ & 24.45 \\
Tensile strength of 2 strand, N/mm & 30.60 \\
Elongation at break, mm & 5.58 \\
Colour & shiny white \\
\hline
\end{tabular}

Table 2 Chemical and physical properties of PSA (Olusola and Umoh, 2013)

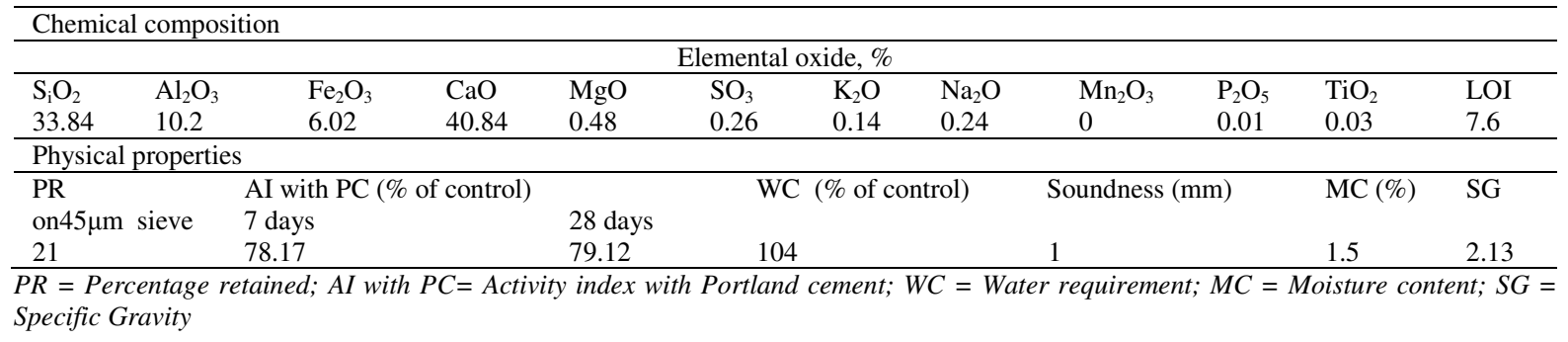

Proportioning and Mixing of Constituents: Water to be used for the fibre reinforced concrete was a portable drinking water from the Civil Engineering
Department, Material/Structure Laboratory, Kaduna Polytechnic, Kaduna. The constituent material were hand-mixed at a mixed proportion of 1:2:3 by weight. 
Moulds of size $100 \mathrm{mmx} 100 \mathrm{mmx} 100 \mathrm{~mm}$ were prepared and a trial (control) mix was cast to determine the compressive strength the concrete. Crushed results after 7days, 14days, 21days and 28 days of curing the cubes were obtained. Concrete Cubes were cast using the mould sat 5\%, 10\%, 15\%, $20 \%, 25 \%$ and $30 \%$ replacement of cement with PSA was carried out. $1 \%$ of sisal fibre by weight of solid concrete constituents was cut into $40 \mathrm{~mm}$ constant length and used as reinforcement and curing was done at ambient temperature for 7days, 14days, 21days and 28days.

\section{RESULTS AND DISCUSSION}

Fine aggregate: The particle size distribution analysis shown in table 3 and in figure 1 shows the fine aggregate is well graded and free from silt.

Table 3.Particle size distribution of fine aggregate

\begin{tabular}{llll}
\hline S/N & $\begin{array}{l}\text { Sieve } \\
\text { Size }\end{array}$ & $\begin{array}{l}\text { Percentage } \\
\text { Retained }(\%)\end{array}$ & $\begin{array}{l}\text { Percentage } \\
\text { Passing }(\%)\end{array}$ \\
\hline 1 & $4.76 \mathrm{~mm}$ & 2.9 & 97.1 \\
2 & $2.4 \mathrm{~mm}$ & 8.3 & 88.8 \\
3 & $1.18 \mathrm{~mm}$ & 15.2 & 73.6 \\
4 & $600 \mu \mathrm{m}$ & 13.4 & 60.2 \\
5 & $300 \mu \mathrm{m}$ & 49 & 11.2 \\
6 & $150 \mu \mathrm{m}$ & 9.8 & 1.4 \\
7 & Pan & 1.2 & 0.2 \\
\hline
\end{tabular}

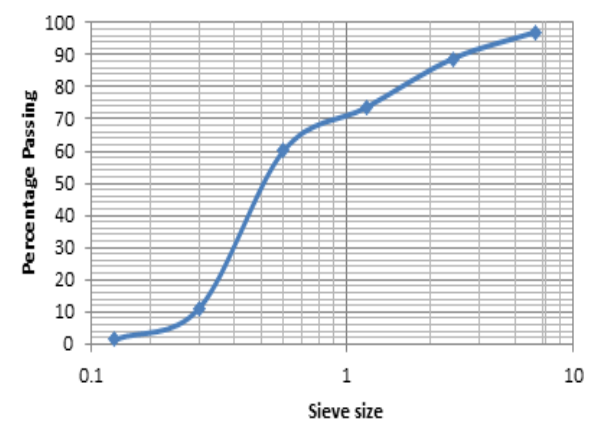

Fig 1 Particle size distribution of fine aggregate

Coarse aggregate: The Coarse aggregate has a specific gravity of 2.73, aggregate impact value of $8 \%$, flakiness and elongation index of $1.6 \%$ and $0.02 \%$ respectively. All these properties agreed with BS 812 Part 101 1984.The sieve analysis report is shown in table 4 below. It is well graded coarse aggregate as the highest percentages of the aggregate were retained on sieve size $12.7 \mathrm{~mm}$ and $19.05 \mathrm{~mm}$.

\begin{tabular}{clll}
\multicolumn{3}{c}{ Table 4Particle size distribution of normal coarse aggregate } \\
\hline S/N & $\begin{array}{l}\text { Sieve } \\
\text { Size }\end{array}$ & $\begin{array}{l}\text { Percentage } \\
\text { Retained }(\%)\end{array}$ & $\begin{array}{l}\text { Percentage } \\
\text { Passing }(\%)\end{array}$ \\
\hline 1 & $38.1 \mathrm{~mm}$ & 0 & 100 \\
2 & $19.05 \mathrm{~mm}$ & 45 & 55 \\
3 & $12.7 \mathrm{~mm}$ & 52.67 & 2.33 \\
4 & $9.5 \mathrm{~mm}$ & 2.33 & 0.00 \\
5 & $6.35 \mathrm{~mm}$ & 0.00 & 0.00 \\
6 & $4.76 \mathrm{~mm}$ & 0.00 & 0.00 \\
9 & $3.55 \mathrm{~mm}$ & 0.00 & 0.00 \\
10 & Pan & 0.00 & 0.00 \\
\hline
\end{tabular}

Workability: The slump test was used to find the consistency of the fresh concrete at 0.5 water/cement ratio for the plain concrete and 0.65 for the PSA/fiberreinforced concrete. The slump result is as shown in figure 2 . The slump value decreases with the increase in the percentage addition of periwinkle shell ash.

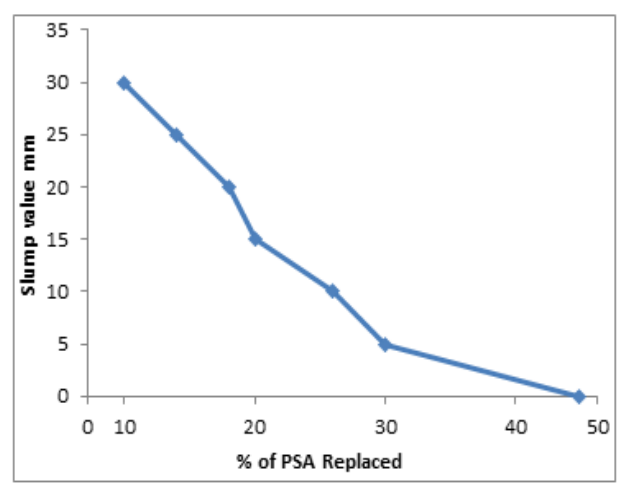

Fig 2 Slump value of Concrete with varied \%PSA Replaced

Concrete Properties/Mix: Trial control mix of 1:2:3 for concrete grade $25 \mathrm{~N} / \mathrm{mm}^{2}$ and w/c ratio of 0.55 was used. The result of the concrete properties is shown in table 5. The compressive strength test results with $0 \%$ PSA shows a consistence increase in strength from $17.15 \mathrm{~N} / \mathrm{mm}^{2}$ to $24.41 \mathrm{~N} / \mathrm{mm}^{2}$.

Table 5.Compressive strength of 0\% PSA replacement

\begin{tabular}{|c|c|c|c|c|c|c|}
\hline Samp & $\begin{array}{l}\text { Age of } \\
\text { Testing }\end{array}$ & $\begin{array}{l}\text { Slump } \\
\text { Valve(mm) }\end{array}$ & $\begin{array}{l}\text { Weight of } \\
\text { Cubes }(\mathrm{Kg})\end{array}$ & $\begin{array}{l}\text { Density of } \\
\text { Cubes }\left(\mathrm{kg} / \mathrm{m}^{3}\right)\end{array}$ & $\begin{array}{l}\text { Crushing } \\
\text { Load }\left(\mathrm{K}_{g}\right)\end{array}$ & $\begin{array}{l}\text { Average Crushing. } \\
\text { Strength }\left(\mathrm{f}_{\mathrm{eu}}\right)\left(\mathrm{N} / \mathrm{mm}^{2}\right)\end{array}$ \\
\hline la & 7 days & 45 & 2.37 & 2370 & 161.9 & 17.15 \\
\hline $\mathrm{lb}$ & & $n$ & 2.39 & 2390 & 169.5 & \\
\hline lc & & $n$ & 2.37 & 2370 & 183.0 & \\
\hline $2 \mathrm{a}$ & 14 days & 45 & 2.40 & 2400 & 205.8 & 20.82 \\
\hline $2 b$ & $\eta$ & $n$ & 2.35 & 2350 & 220.7 & \\
\hline $2 c$ & $\eta$ & $n$ & 2.35 & 2350 & 198.2 & \\
\hline $3 a$ & 21 days & 45 & 2.40 & 2400 & 235.8 & 23.93 \\
\hline $3 b$ & $n$ & $\eta$ & 2.40 & 2400 & 234.9 & \\
\hline $3 c$ & $n$ & $n$ & 2.50 & 2500 & 248.6 & \\
\hline $4 a$ & 28 days & 45 & 2.47 & 2470 & 218.4 & 24.41 \\
\hline $4 b$ & $n$ & $n$ & 2.47 & 2470 & 250.6 & \\
\hline $4 c$ & .. & ... & 2.49 & 2490 & 263.2 & \\
\hline
\end{tabular}

AFOLAYAN, JO; WILSON, UN; ZAPHANIAH, B 
Periwinkle Shell Ash Concrete: It was observed that the inclusion of Sisal fiber in the concrete increases the compressive strength of concrete, the highest value of compressive strength was $28.8 \mathrm{~N} / \mathrm{mm}^{2}$ at $5 \%$ replacement and a cut length of $40 \mathrm{~mm}$ Sisal fiber.

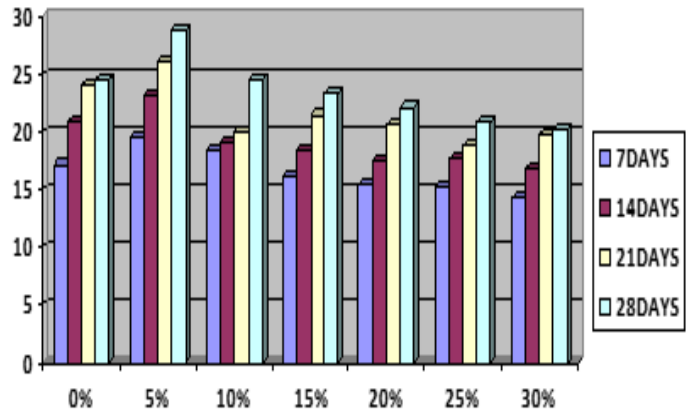

Fig 3Compressive Strength with percentages of Replacement at different curing days

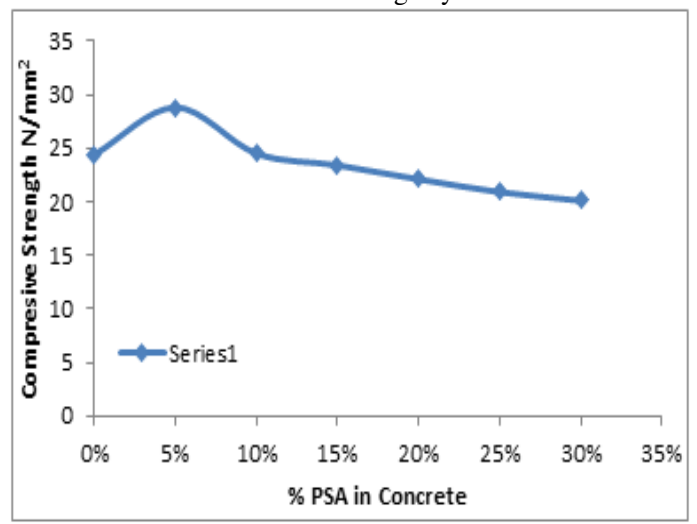

Fig 4.28 Days Curing with Varied Percentage of PSA

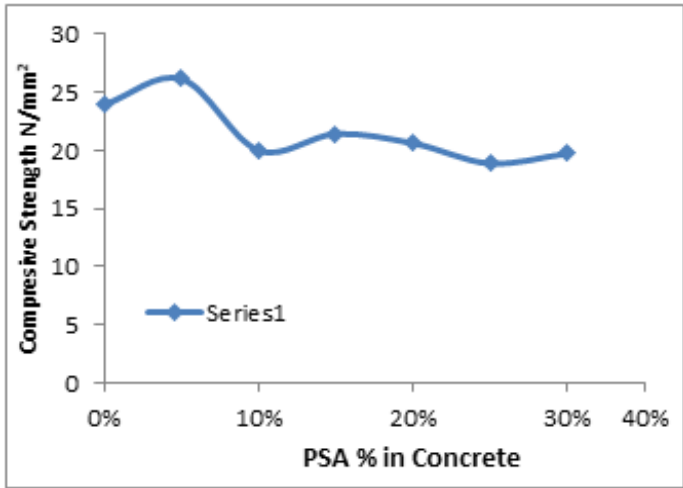

Fig 5. 21 Day Curing with Varied Percentage of PSA

It can be observed that the inclusion of periwinkle shell ash and sisal fiber in a concrete increases the compressive strength of concrete and the highest value of compressive strength was obtained at 5\% replacement of PSA in a sisal fiber-reinforcedconcrete. Significant increase in the compressive strength is recorded in 21 and 28 days of curing whose peaks are at $5 \%$ replacement in fiber-reinforcedconcrete. This invariably shows that 5\% PSA replacement is the optimal PSA content since it gives the maximum compressive strength with the concrete cured at 28days. Also, for $10 \%$ PSA replacement and at a curing age of 28 days, there is an observed increase in compressive strength which is as good as a $0 \%$ PSA replacement at 28 days of curing. From this study, it can therefore be deduced that 5\% PSA replacement can be regarded not only as the optimal PSA content but also as an exclusive PSA content in that, the use of PSA can be narrowed down to the $5 \%$ partial replacement content or not to be used at all, that is, $0 \%$. This is because between 10 and $30 \%$ of PSA, no compressive strengths obtained reaches that gotten at $0 \%$.

Conclusion: The results of the study Sisal fibre can be used as reinforcement to increase the compressive strength of a concrete.The compressive strength obtained decreases as the percentages of replacement increases after 5\% PSA.The compressive strength of concrete at $15 \%$ replacement and at 28 days curing, however, satisfies BS 4550 Part 3 section 3.4 requirements. The use of Sisal fiber at $1 \%$ by weight of the entire concrete mass and of $40 \mathrm{~mm}$ length can be considered an optimal percentage for concrete in view of the highest compressive strength obtained at 28 days curing and is hereby recommended as adequate.

\section{REFERENCES}

ASTM C150: Structural Specification for Portland Cement. American Society for Testing and Materials

British Standards Institution, BS 882 (1992), Specification for Aggregate from Natural Sources for Concrete. British Standards Insttitution, London.

Adesanya, D.A (2001) "The Effects of Thermal Conductivity and Chemical Attack on Corb Cob Ash Blended Cement" Professional Builder, 66(5), 3-10.

Adesanya, D.A and Raheem, A.A. (2009a) "Development of Corn Cob Ash Blended Cement" Construction and Bulding Materials, 23(1), 348-352.

Adesanya, D.A and Raheem, A.A. (2009b) “A Study of the Workability and Comprehensive Strength Characteristics of Corn Cob Ash Blended Cement Concrete" Construction and Building Materials, 23(1), 311-317. 
Badmus, M.A.O, Audu, T.O.K, and Anyata, B.U. (2007) "Removal of Lead ion from Industrial Wastewater by Activated Carbon Prepared from Periwinkle Shell ( typanotonus fuscatus)" Turkish Journal of Engineering and Environmental Science, 31, 251-263

Bhavikatti, S.S (2010). Basic Civil Engineering, New Age International (P) Ltd Publishers, New Delhi.

Dahunsi, B.I.O and Bamisaye, J.A (2002) "Use of periwinkle Shell Ash ( PSA) as Partial Replacementt for Cement In Concrete" Proceeding Nigerian Materials Congress and meeting of Nigerian Materials Research Society, Akure, Nigeria, 184-186.

Dance, S.P (1980). The Ecyclopaedia of Shells. Littlehampton Book Services Ltd., Faraday Close Worthing, West Sussex limited, United Kingdom

Jamabo, N and Chinda, A. (2010) "Aspects of the Ecology of tympanonous fuscatus varfuscastus ( lnnaeus, 1758) in the Mangrove Swamps of the Upper Bonny River, Niger delta, Nigeria”. Current Research Journal of Biology Sciences, 291), 42-47.

Job, O.F (2008) "The Durability Characteristics of Periwinkle shell Concrete, Ph.D thesis, University of Jos, Nigeria.

Koffi, N. E. (2008) "Commpresive Strength of Concrete Incorporating Periwinkle Shell Ash. Unpublished B.Sc Project, University of Uyo, Nigeria.

Mmom, P.C and Arokoya, S.B (2010) "Mangrove Forest Depletion Biodiversity Loss and Traditional Resources Management Practice In Niger Delta, Nigeria" Research Journal of Applied Sciences, Engineering and Technology, “ 2(1), 28-34

Neville A. Am (1983).Properties of Concrete, $3^{\text {rd }}$ ed., Pitman Pub. London.
Okon, B.I. (1987).'Utilization of Periwinkle Flesh by Broilers Feed Palm Kernel Based rations Ph.D thesis, University of Ibadan, Nigeria

Olorunoje, G.S and Olalusi, O.C (2003) "Periwinkles Shell as Alternative to Coarse Aggregate in Lightweight Concrete" International Journal of Environment Issues 1(1), 231-236.

Olutoge, F.A., Buari, T.A and Adeleke, J.S. (2013), "Characteristics Strength and Durability of Groundnut Shell Ash (GSA) Blended Cement Concrete in Sulphate Environment" International Journal of Scientific and Engineering, Vol 4.

Powell, C.B., Hart, A.I., Deekae, S. (1985) "Market Survey of the Periwinkls typanotonus fuscatus in River State: Size, Prices, proceeding of the 4th Annual conference of Fisheries society of Nigeria (FISON) Port harcourt, Nigeria.

Sani, J.E., Afolayan, J.O., Chukwujama, I.A and Johanna, P. (2017)“"Effect of Wood Saw Dust Ash Admixed with Treated fibre on Geotechnical Properties of Lateritic Soil'Leonard Electronic Journal of Practices and Technologies. Issue 31, July- December pp 59-76.

Sumaila, S.A and Job. O.F (1999) "Properties of SDAOPC Concrete a preliminary assessment". Journal of Environment Sciences, 3(1-3), 155-159.

Tangchirapat, W., Jaturapilatkul, c., Chindaprasirt, P. (2009)" Use of Palm oil Fuel ash as a supplementary cenmentitious Material for producing high strength concrete and building Materia". Construction and building materials, 2 (7) , 2641-246.

Udoeyo, F.F and Dashibil, P.U. (2002) "Sawdust ash as Concrete Materials" Journal of Materials in Civil Engineering 14(2), 173-176.

Zhung, M.H and Malhotra, M.H (1996), "High Performance Concrete Incorporating Rice Hush as Supplementary Cementing Material" ACI Material Journal, 93(6), 629-636. 